\title{
Comparison of yield characteristics of Damascus and Kilis goats in dry climatic conditions
}

\author{
Ali Murat Tatar ${ }^{a}$, Selçuk Seçkin Tuncer ${ }^{b *}$, Halit Deniz Şireli ${ }^{\mathrm{a}}$
}

\begin{abstract}
The aim of this study was to compare the reproductive traits, lactation milk yield, and body measurements of the Damascus (Shami) and Kilis goats raised as dairy goats in the dry climatic conditions of the Southeastern Anatolia region of Turkey. The study was perfomed using 596 Damascus goats and 82 Kilis goats between 3-5 years old. It was observed that the lactation milk yield, lactation period, withers height, and leg circumference of the Damascus goats $(175.86 \mathrm{~kg}, 227.48$ days, $72.67 \mathrm{~cm}$, and 74.10 $\mathrm{cm}$, respectively) were significantly higher $(P<0.05)$ than those of the Kilis goats $(107.48 \mathrm{~kg}, 170.39$ days, $69.70 \mathrm{~cm}$ and $71.83 \mathrm{~cm}$, respectively). This analysis indicated that the Damascus goat may be a good breed for dry climatic conditions. It is suggested that focusing on growing Damascus goats could increase productivity in the Southeastern Anatolian region of Turkey.

Key words: goat, body measurements, reproductive, lactation traits.
\end{abstract}

\section{INTRODUCTION}

As of 2017, although the total number of goats in Turkey $(11,010,590$ heads) was close to that of the entire European Union (12,615,362 heads), the annual milk production of Turkey (463,270 tons) is one-quarter of the volume of milk produced in the countries of the European Union (1,931,676 tons) (FAO 2017). The low goat milk production in Turkey is due to an overwhelming majority of its stock, as high as $98 \%$, consisting of the hair goat (TUIK 2017), while only $2 \%$ are Cashmere goats (Angora) and dairy goats, such as the Damascus and Kilis goats (Tuncel and Bayındir 1983, Ilgar and Kircan 2016). This is an indicator of the shortcomings of the milk yield-oriented goat breeding studies carried out in Turkey since the 1960s (Kaymakçı et al 2005, Atay 2016).

The Southeastern Anatolia region holds important potential for goat breeding. According to 2016 data, the region provides $22.6 \%$ of the goat stock and $24.1 \%$ of the goat milk production in Turkey (TUIK 2017).

In Turkey, the Damascus (Keskin 2000) and Kilis goats (Keskin and Tüney 2015) are bred in the Mediterranean and Southeastern Anatolia regions. The most prominent features of the Damascus goats include its adaption to high temperatures and suitability for breeding in plain areas (lowlands); it has an advantage over sheep in terms of its reproductive ability to benefit from arid pastures (Barıtçı and Adigüzel 2017).

Received 19.04.2018.

Accepted: 23.11.2018.

aDepartment of Animal Science, Faculty of Agriculture, University of Dicle, Diyarbakir, Turkey.

bepartment of Crop and Animal Production, Ozalp Vocational School, University of Van Yuzuncu Yil, Van, Turkey.

*Corresponding Author: SS Tuncer; selcukseckintuncer@gmail.com
As in all economic activities, the goal of goat breeding is to earn profits. In order to increase profitability, it is necessary to increase fertility. An increase in goat farm production can be achieved by increasing the number of births and the number of kids at birth (Erten and Yilmaz 2013). Fertility is the most important yield trait in continuing the lineage, commencing milk production, and providing stock for meat production (Keskin et al 2016).

Reproductive traits are determined by environmental conditions, rather than genotypic factors. Therefore, the progress achieved with genetic selection alone is reduced. On the other hand, following some simple rules while selecting a breeding animal will contribute to an increase in reproductive yields, albeit at a slower pace than that of selection. While selecting breeding animals, giving priority to twin does or bucks and being careful to select animals among the progenies of twin parents, or selecting the breeding animals from families with high reproductive yield will lead to a slightly increased reproductive yield in the next generations (Çam et al 2012, Tozlu and Oflaz 2015).

In this study, the reproductive traits of the Damascus and Kilis goats of varying ages were investigated to determine their potential for use in the breeding studies carried out in the important goat-breeding region of Southeastern Anatolia in Turkey.

\section{MATERIAL AND METHODS}

The study was carried out on an experimental goat farm $\left(37^{0} 50^{\prime} 55^{\prime}\right.$ 'N $40^{0} 39$ ' 57" E) in Bismil. The lowest altitude (546 m), Bismil district, in Diyarbakir province, where the study was carried out, was found to have moderate dry climate conditions during the study period. Diyarbakır is a city in the Southeastern Anatolia region of Turkey with an average temperature of $15.8^{\circ} \mathrm{C}$ according to long-term meteorological data (1929-2016) (Anonymous 2017). The animals used in the study consisted of 3 to 5 year-old Damascus $(n=596)$ and Kilis goats $(n=82)$. 
The goats were grouped according to their milk yields and daily feed requirements were determined by taking their milk yields into account. Vetch fodder grown by the establishment was used as roughage and as a concentrate feed. The sheep and goat milk feed, a mixture also prepared by the establishment that contains $17.9 \%$ crude protein and $3 \mathrm{Mcal} / \mathrm{Kg}$ metabolic energy was comprised of barley, soybean meal, bran, mineral-vitamin premix, ground limestone, and salt (table 1). The mixture was provided twice daily, in the morning and evening. Fresh and clean water was provided for the animals. Milking was performed two times a day (early in the morning and towards the evening). Attention was given to taking an 8-hour break on average between two milking processes. The milking process was carried out with the aid of an automatic milking machine and all the data for milk were recorded in the herd registry system.

The births occurred from February to March. The live weights of the goats and kids after birth were determined using precision scales sensitive to $50 \mathrm{~g}$. The kids were kept with the dams during a 15-day period after birth and then were separated from the dams and transferred to a separated kid pen. Within the pen, the kids were allowed to suckle the dams two times a day until weaning.

The milk records were obtained from the herd management program maintained at the goat farm.

Of the body measurements of interest in the study, withers heights (WH), body length (BL), chest depth (CD), and chest width $(\mathrm{CW})$ were measured using a measurement stick, and chest girth (CG) and leg circumference (LC) were measured using a measuring tape (Cengiz et al 1989).

Birth rate, infertility rate, litter size, and single, twin or triplet birth rate, as reproductive features, were all calculated by the method proposed by Kaymakçı and Sonmez (1996).

Statistical evaluation was performed using SAS (2018). Multivariate Anova was used to evaluate the effect of gender, type of birth and age on birth weight. Independent t-test was used to obtain the differences between the goat breeds on birth weight.

\section{RESULTS}

Table 2 shows the descriptive values for reproductive traits obtained in this study. According to the table, there is no statistical difference in point of reproductive performance between goat breeds.

Table 3 shows the birth weights of the Damascus and Kilis kids. The birth weights of the male kids of both the Damascus and Kilis goats were significantly higher $(\mathrm{P}<0.05)$ than those of the female kids. The highest $(P<0.05)$ birth weight was observed in single-birth type in Damascus goats, while the lowest birth weight was found in the 5 -year age group. In Kilis goats, the highest $(P<0.05)$ birth weight was found in single and twin births and in the age group of 3 years.
Table 1. Composition and nutrient contents of the feed used in the research.

\begin{tabular}{lr}
\hline Ingredients & $\mathrm{g} / \mathrm{kg}$ \\
\hline Barley & 646.9 \\
Soyabean meal & 131.0 \\
Wheat bran & 187.6 \\
Mineral-vitamin premix & 2.5 \\
Ground limestone & 24.5 \\
Common salt & 7.5 \\
& \\
Chemical composition (DM basis) & $\%$ \\
Dry matter & 89.0 \\
Crude Protein & 17.9 \\
Crude fiber & 7.8 \\
Ether extract & 2.4 \\
Crude ash & 3.9 \\
Calcum & 1.1 \\
Phosphorus & 0.6 \\
Metabolizable energy (Mcal/kg) & 3.0 \\
\hline
\end{tabular}

Table 4 shows the descriptive values for the lactation milk yield and lactation period of the Damascus and Kilis goats. The lactation milk yield of 5-year-old Damascus and Kilis goats and the length lactation period of 5-year-old Kilis goat were lower than the other age groups $(P<0.05)$. The lactation milk yield and lactation period of the Damascus and Kilis goats were $175.86 \mathrm{~kg}$ and $107.48 \mathrm{~kg}$, and 227.48 days and 170.39 days, respectively. It was found that the average milk yield and lactation period of Damascus goats were higher than Kilis goats $(P<0.05)$.

Table 5 shows the descriptive values for the body measurements of the Damascus and Kilis goats As seen in Table 5, WH and LC of the Damascus goats were higher $(P<0.05)$ than those of the Kilis goats.

As shown in table 6, in the Damascus goats, there were high correlations $(P<0.01)$ between LW and CD $(0.693)$, LW and CG (0.742), LW and LC (0.600), WH and LC (0.517), CW and CG (0.670), CW and LC (0.573), and CG and LC (0.572).

In the Kilis goats (table 7), there were high correlations $(P<0.01)$ between LW and BL $(0.660), \mathrm{LW}$ and $\mathrm{CD}$ (0.566), LW and CW (0.629), LW and CG (0.673), LW and LC (0.597), BL and LC (0.485), CD and CW (0.496), $\mathrm{CD}$ and CG (0.707), CW and CG (0.739).

\section{DISCUSSION}

Almost all the reproductive traits of the Damascus goats were higher than those of the Kilis goats (table 2). The birth rate of the Damascus goats $(99.30 \%)$ was similar to that reported by Keskin et al (2016) in Damascus goats, while the birth rate of the Kilis goats (93.90\%) was higher than that reported in the same literature for the Kilis x Hair goat crossbreeds. The multiple birth rates of the Damascus and Kilis goats were lower (Gül et al 2010, Keskin et al 
Table 2. The descriptive values for the reproductive traits of the Damascus and Kilis goats.

\begin{tabular}{|c|c|c|c|c|}
\hline & \multicolumn{2}{|c|}{ Damascus } & \multicolumn{2}{|c|}{ Kilis } \\
\hline & $\mathrm{n}$ & $\%$ & $\mathrm{n}$ & $\%$ \\
\hline Infertility rate & 28 & 4.70 & - & - \\
\hline Gestation rate & 568 & 95.30 & 82 & 100.00 \\
\hline Number of birth & 564 & 99.30 & 77 & 93.90 \\
\hline Single kidding & 303 & 53.35 & 47 & 57.32 \\
\hline Twin kidding & 237 & 41.73 & 29 & 35.37 \\
\hline Triplet kidding & 23 & 4.08 & 1 & 1.22 \\
\hline Quadruplet kidding & 1 & 0.18 & - & - \\
\hline Livebirth & 850 & & 108 & \\
\hline Abortion & 9 & 1.58 & 1 & 1.30 \\
\hline Stillbirth & 4 & 0.70 & 4 & 4.88 \\
\hline Litter size & & 150.70 & & 140.00 \\
\hline
\end{tabular}

Table 3. The birth weights $(\mathrm{kg})$ of the Damascus and Kilis kids.

\begin{tabular}{|c|c|c|c|c|c|}
\hline & & \multicolumn{2}{|c|}{ Damascus } & \multicolumn{2}{|c|}{ Kilis } \\
\hline & & $\mathrm{n}$ & $\bar{X} \pm S_{x}$ & $\mathrm{n}$ & $\bar{X} \pm S_{x}$ \\
\hline \multirow[t]{2}{*}{ Sex } & Female & 423 & $3.50 \pm 0.03 b$ & 44 & $3.44 \pm 0.10 \mathrm{~b}$ \\
\hline & Male & 427 & $3.89 \pm 0.04 \mathrm{a}$ & 64 & $3.78 \pm 0.08 \mathrm{a}$ \\
\hline \multirow[t]{4}{*}{ Birth type } & Single & 303 & $3.91 \pm 0.04 \mathrm{a}$ & 47 & $3.88 \pm 0.10 \mathrm{a}$ \\
\hline & Twin & 476 & $3.61 \pm 0.03 b$ & 58 & $3.49 \pm 0.07 \mathrm{ab}$ \\
\hline & Triplet & 69 & $3.37 \pm 0.08 \mathrm{c}$ & 3 & $3.07 \pm 0.75 b$ \\
\hline & Quadruplet & 4 & $3.67 \pm 0.24 b$ & - & - \\
\hline \multirow[t]{3}{*}{ Age } & 3 & 253 & $3.89 \pm 0.22 \mathrm{a}$ & 16 & $3.90 \pm 0.45 \mathrm{a}$ \\
\hline & 4 & 345 & $3.91 \pm 0.16 \mathrm{a}$ & 68 & $3.42 \pm 0.13 b$ \\
\hline & 5 & 252 & $3.64 \pm 0.22 b$ & 24 & $3.49 \pm 0.31 b$ \\
\hline Total & & 850 & $3.69 \pm 0.02 \mathrm{~A}$ & 108 & $3.64 \pm 0.66 \mathrm{~A}$ \\
\hline
\end{tabular}

$\bar{X} \pm S_{x}:$ mean \pm standart error.

a, b, c: Different lower cases in the same column represent statistically significant differences $(P<0.05)$.

A, B: Different capital letters in the same row represent statistically significant differences $(P<0.05)$.

Table 4. The lactation milk yields $(\mathrm{kg})$ and lactation period (day) of the Damascus and Kilis goats.

\begin{tabular}{lccccc}
\hline & & \multicolumn{2}{c}{ Damascus } & & \multicolumn{2}{c}{ Kilis } \\
\cline { 3 - 6 } & Age & $\mathrm{n}$ & $\bar{X} \pm S_{x}$ & & $\mathrm{n}$ \\
\hline Lactation milk yield & 3 & 224 & $176.26 \pm 24.49 \mathrm{a}$ & 17 & $109.40 \pm 35.31 \mathrm{a}$ \\
& 4 & 248 & $180.60 \pm 35.17 \mathrm{a}$ & 49 & $112.46 \pm 59.58 \mathrm{a}$ \\
& 5 & 124 & $165.68 \pm 27.29 \mathrm{~b}$ & 16 & $90.60 \pm 27.71 \mathrm{~b}$ \\
Total & & 596 & $175.86 \pm 29.23 \mathrm{~A}$ & 82 & $107.48 \pm 50.04 \mathrm{~B}$ \\
Lactation period & 3 & 224 & $229.45 \pm 31.70 \mathrm{a}$ & 17 & $174.78 \pm 47.57 \mathrm{a}$ \\
& 4 & 248 & $225.76 \pm 39.80 \mathrm{a}$ & 49 & $173.98 \pm 38.48 \mathrm{a}$ \\
Total & 5 & 124 & $227.38 \pm 29.81 \mathrm{a}$ & 16 & $155.23 \pm 20.83 \mathrm{~b}$ \\
\hline
\end{tabular}

a, b: Different lower cases in the same lines represent statistically significant differences $(P<0.05)$.

A, B: Different capital letters in the same row represent statistically significant differences $(P<0.05)$. 
Table 5. Body measurements of the Damascus and Kilis goats.

\begin{tabular}{|c|c|c|c|c|c|}
\hline & \multirow{2}{*}{ Age } & \multicolumn{2}{|c|}{ Damascus } & \multicolumn{2}{|c|}{ Kilis } \\
\hline & & $\mathrm{n}$ & $\bar{X} \pm S_{x}$ & $\mathrm{n}$ & $\bar{X} \pm S_{x}$ \\
\hline $\begin{array}{l}\text { Withers height } \\
(\mathrm{cm})\end{array}$ & $\begin{array}{l}3 \\
4 \\
5\end{array}$ & $\begin{array}{l}224 \\
248 \\
124\end{array}$ & $\begin{array}{l}71.89 \pm 4.31 \\
73.30 \pm 2.68 \\
72.80 \pm 3.42\end{array}$ & $\begin{array}{l}17 \\
49 \\
16\end{array}$ & $\begin{array}{l}68.75 \pm 1.75 \\
70.06 \pm 3.43 \\
69.58 \pm 2.13\end{array}$ \\
\hline Total & & 596 & $72.67 \pm 3.42 \mathrm{a}$ & 82 & $69.70 \pm 2.91 b$ \\
\hline $\begin{array}{l}\text { Body length } \\
(\mathrm{cm})\end{array}$ & $\begin{array}{l}3 \\
4 \\
5\end{array}$ & $\begin{array}{l}224 \\
248 \\
124\end{array}$ & $\begin{array}{l}74.89 \pm 3.63 \\
76.30 \pm 2.64 \\
73.10 \pm 7.25\end{array}$ & $\begin{array}{l}17 \\
49 \\
16\end{array}$ & $\begin{array}{l}73.58 \pm 2.22 \\
74.31 \pm 3.02 \\
72.83 \pm 2.71\end{array}$ \\
\hline Total & & 596 & $75.10 \pm 4.24$ & 82 & $73.87 \pm 2.79$ \\
\hline $\begin{array}{l}\text { Chest depth } \\
(\mathrm{cm})\end{array}$ & $\begin{array}{l}3 \\
4 \\
5\end{array}$ & $\begin{array}{l}224 \\
248 \\
124\end{array}$ & $\begin{array}{l}32.11 \pm 1.50 \\
33.45 \pm 1.79 \\
34.00 \pm 1.00\end{array}$ & $\begin{array}{l}17 \\
49 \\
16\end{array}$ & $\begin{array}{l}31.92 \pm 1.50 \\
32.78 \pm 1.33 \\
32.67 \pm 1.40\end{array}$ \\
\hline Total & & 596 & $33.06 \pm 1.68$ & & $32.58 \pm 1.37$ \\
\hline $\begin{array}{l}\text { Chest width } \\
(\mathrm{cm})\end{array}$ & $\begin{array}{l}3 \\
4 \\
5\end{array}$ & $\begin{array}{l}224 \\
248 \\
124\end{array}$ & $\begin{array}{l}19.56 \pm 1.72 \\
21.35 \pm 2.04 \\
20.50 \pm 0.71\end{array}$ & $\begin{array}{l}17 \\
49 \\
16\end{array}$ & $\begin{array}{l}19.50 \pm 1.95 \\
20.56 \pm 1.97 \\
20.83 \pm 2.42\end{array}$ \\
\hline Total & & 596 & $20.50 \pm 1.85$ & 82 & $20.40 \pm 2.04$ \\
\hline $\begin{array}{l}\text { Chest girth } \\
(\mathrm{cm})\end{array}$ & $\begin{array}{l}3 \\
4 \\
5\end{array}$ & $\begin{array}{l}224 \\
248 \\
124\end{array}$ & $\begin{array}{l}90.44 \pm 5.13 \\
93.90 \pm 4.42 \\
95.10 \pm 3.01\end{array}$ & $\begin{array}{l}17 \\
49 \\
16\end{array}$ & $\begin{array}{l}89.92 \pm 5.99 \\
93.42 \pm 4.88 \\
93.00 \pm 4.87\end{array}$ \\
\hline Total & & 596 & $92.85 \pm 4.71$ & 82 & $92.63 \pm 5.12$ \\
\hline $\begin{array}{l}\text { Leg circumference } \\
(\mathrm{cm})\end{array}$ & $\begin{array}{l}3 \\
4 \\
5\end{array}$ & $\begin{array}{l}224 \\
248 \\
124\end{array}$ & $\begin{array}{l}73.06 \pm 2.74 \\
74.80 \pm 1.55 \\
74.60 \pm 1.82\end{array}$ & $\begin{array}{l}17 \\
49 \\
16\end{array}$ & $\begin{array}{c}70.50 \pm 1.67 \\
72.58 \pm 2.29 \\
70.92 \pm 3.41\end{array}$ \\
\hline Total & & 596 & $74.10 \pm 2.20 \mathrm{a}$ & 82 & $71.83 \pm 2.54 b$ \\
\hline
\end{tabular}

a, b: Different lower cases in the same lines represent statistically significant differences $(P<0.05)$.

Table 6. The relationships between the live weight and body measurements of the Damascus goats.

\begin{tabular}{|c|c|c|c|c|c|c|}
\hline & LW & WH & BL & $\mathrm{CD}$ & $\mathrm{CW}$ & CG \\
\hline WH & $0.447 *$ & & & & & \\
\hline BL & 0.045 & $0.415^{*}$ & & & & \\
\hline $\mathrm{CD}$ & $0.693 * *$ & $0.508^{*}$ & 0.227 & & & \\
\hline $\mathrm{CW}$ & $0.511 *$ & 0.294 & 0.185 & $0.537 *$ & & \\
\hline CG & $0.742 * *$ & $0.448^{*}$ & 0.055 & $0.547 *$ & $0.670 * *$ & \\
\hline $\mathrm{LC}$ & $0.600 * *$ & $0.517 * *$ & 0.195 & $0.441 *$ & $0.573 * *$ & $0.572 * *$ \\
\hline
\end{tabular}

${ }^{*}: P<0.05$. $^{* *}: P<0.01$.

LW: Live Weight; WH: Withers Height; BL: Body Length; CD: Chest Depth; CW: Chest Width; CG: Chest Girth; LC: Leg Circumference.

Table 7. The relationships between the live weight and body measurements of the Kilis goats.

\begin{tabular}{lllllll}
\hline & LW & WH & BL & CD & CW & CG \\
\hline WH & 0.213 & & & & & \\
BL & $0.660^{* *}$ & 0.216 & & & & \\
CD & $0.566^{* *}$ & 0.186 & 0.235 & & & \\
CW & $0.629^{* *}$ & -0.120 & 0.279 & $0.496^{* *}$ & & \\
CG & $0.673^{* *}$ & -0.042 & 0.305 & $0.707^{* *}$ & $0.739^{* *}$ & \\
LC & $0.597^{* *}$ & $0.424^{*}$ & $0.485^{* *}$ & 0.323 & $0.421^{*}$ & $0.399^{*}$ \\
\hline
\end{tabular}

${ }^{*}: P<0.05 .{ }^{* *}: P<0.01$. 
2016) or higher (Keskin and Biçer 1997, Keskin 2000) than those reported in some studies of the Damascus and Kilis $\mathrm{x}$ Hair goat crossbreeds. In this study, the litter sizes of Damascus and Kilis goats (150.7\% and $140.3 \%)$ were lower than those reported by Keskin et al (2016) in Damascus goats and Kilis x Hair goat crossbreeds (180\% and $162.5 \%$ ), but higher than those reported by Kutlu (1990) in Akkeçi x Kilis and Saanen x Kilis goat crossbreeds (124.2\% and 132.9\%). The Damascus goat is recommended as a fertile goat breed in view of its good adaptability (Barıtçı and Adıgüzel 2017); the favorable results obtained in this study and also previous studies show that it has a higher litter size than that of the Nubian, Pygmy, American Alpine, French Alpine, Saanen, and Toggenburg goats (Amoah et al 1996), which are among the most fertile goats in the world.

A comparison of birth weights of the Damascus and Kilis kids (table 3), in terms of their sex and birth types, revealed that the birth weights of the male kids were significantly higher $(P<0.05)$ than those of the female kids, and the birth weights of the kids from single births were slightly higher than those of the kids from multiple births. This result is compatible with those reported in other literature (Şimşek et al 2007, Akbaş et al 2013, Keskin et al 2016). The mean birth weights of the Damascus and Kilis goats were higher than those of the Saanen $X$ Hair goat $F_{1}$ and $G_{1}$ crossbreeds (Şimşek et al 2007), Saanen (Akbaş et al 2013), Damascus, and Kilis x Hair goat crossbreeds (Keskin et al 2016 ). A comparison of birth weights with respect to the ages of the dams showed that the birth weights of kids of 3- and 4-year-old dams in Damascus and the birth weights of kids of 3-year-old dams in Kilis goats were slightly higher than kids of the dams at other ages.

The data showed (table 4 ) that the lactation milk yield and lactation period of the Damascus and Kilis goats were lower than those reported by Keskin (2000), Keskin et al (2004), Özuyanık (2004), Kaymakçı et al (2005) and Keskin et al (2016) in Damascus goats.

Table 5 shows the descriptive values for the body measurements of the Damascus and Kilis goats. The average WH of the Damascus and Kilis goats were higher than those reported by Aktepe (2009) in Kilis goats and by Bingöl et al (2011) in Norduz goats, but similar to those reported by Barıtçı and Adıgüzel (2017) in Damascus and by Ünalan and Ceyhan (2017) in Kilis goats. The average BL of the Damascus and Kilis goats $(75.10 \mathrm{~cm}$ and $73.87 \mathrm{~cm}$, respectively) were higher than those of Kilis goats (Aktepe, 2009, Alızadehasl and Ünal 2011, Ünalan and Ceyhan 2017), and similar to those of Damascus goats (Barıtçı and Adıgüzel 2017). The average CD of the Damascus and Kilis goats $(33.06 \mathrm{~cm}$ and $32.58 \mathrm{~cm}$, respectively) were higher than those reported by Aktepe (2009), Alızadehasl and Ünal (2011), and Ünalan and Ceyhan (2017) in Kilis goats, by Bingöl et al (2011) in Norduz goats, and by Karakuş (2016) in Hair goats and Saanen goats. The average CW of the Damascus and Kilis goats $(20.50 \mathrm{~cm}$ and $20.40 \mathrm{~cm}$, respectively) were higher than those reported by Karakuş (2016) in Hair goats and Saanen goats and by Barıtçı and Adigüzel (2017) in Damascus goats, but similar to those reported by Bingöl et al (2011) and Ünalan and Ceyhan (2017) in Kilis goats. The LC of the Damascus and Kilis goats $(74.10 \mathrm{~cm}$ and $71.83 \mathrm{~cm}$, respectively) were higher than those of the Norduz goats (Bingöl et al 2011).

As seen in Table 6, in the Damascus goats, there were high correlations $(\mathrm{P}<0.01)$ between LW and CD $(0.693)$, LW and CG (0.742), and LW and LC (0.600), which agree with results from the studies that reported high correlations $(P<0.01)$ between the live weights and body measurements of the Sanen, Kilis, and Hair goats (Pesmen and Yardimci 2008, Çam et al 2012, Alızadehasl and Ünal 2011).

As shown in table 7, the high and significant correlation $(P<0.01)$ between $\mathrm{CW}$ and $\mathrm{CG}, \mathrm{CD}$ and $\mathrm{CG}$, and $\mathrm{CW}$ and $\mathrm{CG}$ in the Kilis goats agrees with results reported in the scientific literature (Cam et al 2010, Sariyel 2013, Karakuş 2016).

It is concluded that the litter size, lactation milk yield, lactation period, $\mathrm{WH}$ and, $\mathrm{LC}$ of the Damascus goats were significantly higher than those of the Kilis goats. This analysis indicates that the Damascus goat may be better than Kilis goat breed for the dry climate of the important goat-breeding region of the Southeastern Anatolia region in Turkey. Based on the findings in that particular region of Turkey, it may be beneficial to compare the raising of Damascus goats in other parts of Turkey, or the world, with similar climates.

\section{REFERENCES}

Akbaş AA, Çolak M, Elmaz Ö, Saatçı M. 2013. Determination of growth performance of the Saanen kids reared in North-West Mediterranean condition. Eurasian J Vet Sci 29, 70-75.

Aktepe T. 2009. A study on determınıng anatomical, morphological and physiological adaptation parameters of Kilis goats. Master's Thesis, Institute of Natural and Applied Sciences University of Çukurova, Adana, Turkey.

Alızadehasl M, Ünal N. 2011. Some morphological traits of Kilis, Norduz and Honamlı indigenous goats breeds. $J$ Lalahan Lives Res Inst 51, 81-92.

Amoah, EA, Gelaye S, Guthrie P, Rexroad CE. 1996. Breeding season and aspects of reproduction of female goats. JAnim Sci 74, 723-728.

Anonymous. 2017. Turkish State Meteorological Service. Official statistics for meteorological parameters of cities. Goverment of Turkey, Ankara, Turkey.

Atay O. 2016. Fattening performance, carcass and meat quality characteristics of Alpine x Hair Goat (F1), Saanen x Hair goat (F1) and Hair goat kids. J Tekirdag Agri Fac 13, 129-133.

Barıtçı I, Adıgüzel C. 2017. Aleppo (Damascus) goat breeding. Dicle Univ J Inst Nat Applied Sci 6, 39-42.

Bingöl M, Gökdal Ö, Aygün T, Yılmaz A, Daşkıran İ. 2011. Some productive characteristics and body measurements of Norduz goats. $7^{\text {th }}$ National Animal Science Congress, September 14-16, Adana, Turkey.

Cam MA, Olfaz M, Soydan E. 2010. Possibilities of using morphometrics characteristics as a tool for body weight prediction in Turkish Hair goats (Kil keci). Asian J Anim Vet Adv 5, 52-59.

Çam MA, Olfaz M, Kırıkçı K, Soydan E, Kuran M. 2012. Karayaka breeding potential in terms of fertility. International Animal Science Congress of Turkish and Relatives Communities, September 11-13, Isparta, Turkey, Pp 134-140. 
Cengiz F, Eliçin A, Ertuğrul M, Arık İZ. 1989. Fattening performance and carcass characteristics in Akkaraman, Ile de France x Akkaraman $\left(F_{1}\right)$, Anatolian Merino and Ile de France $x$ Anatolian Merino $\left(F_{1}\right)$ male lambs. Ankara University Faculty of Agriculture Publications, Ankara, Turkey.

Erten Ö, Y1lmaz O. 2013. Investigation of reproductive and milk yield traits of Hair goats raised under extensive conditions. Van Vet $J$ 24, 105-107.

FAO, Food and Agriculture Organization. 2017. Livestock Primary. Food and Agriculture Organization of the United Nations.

Gül S, Keskin M, Biçer O. 2010. Comparison of performance of different goat genotypes in Eastern Mediterranean Region conditions: 2. yield properties. National Goat Congress, June 24-26, Çanakkale, Turkey.

Ilgar R, Kırcan S. 2016. Goats activities of Çanakkale province. Inönü Univ Int J Soc Sci 3, 52-86.

Karakuş F. 2016. The effect of body condition score on fertility, live weight and some body measurements in goats. YYU J Agr Sci 26, 372-379.

Kaymakçı M, Sönmez R. 1996. Sheep Breeding. İzmir, Turkey.

Kaymakçı M, Tuncel E, Güney O. 2005. Dairy goat breeding studies in Turkey. National Dairy Goat Congress, May 26-27, İzmir, Turkey.

Keskin M, Biçer O. 1997. Some morphological and physiological characteristics of goats bred in Hatay region. J Agricultural Faculty $M K U$ 2, 73-86.

Keskin M. 2000. Comparison of morphological characteristics and performance of Damascus goats in the intensive breeding conditions in Hatay region. PhD Dissertation, Institute of Natural and Applied Sciences, University of Mustafa Kemal, Hatay, Turkey.

Keskin M, Avşar YK, Biçer O, Güler MB. 2004. A comparative study on the milk yield and milk composition of two different goat genotypes under the climate of the Eastern Mediterranean. Turk $J$ Vet Anim Sci 28, 531-536.

Keskin M, Tüney D. 2015. Relationship between body condition score and reproductive characteristics in Kilis goat. J Agricultural Faculty $M K U$ 20, 60-65.
Keskin M, Gül S, Can E, Gündüz Z. 2016. Milk yield and reproductive traits of Shami and KilisxHair goat crossbred genotypes under semi-intensive conditions. J Lalahan Lives Res Inst 56, 20-24.

Kutlu MB. 1990. A research on fattening carcass performance in AkkeçixKilis and SaanenxKilis crossbreds in Ceylanpınar Agricultural Operation. Master's Thesis, Institute of Natural and Applied Sciences University of Çukurova, Adana, Turkey.

Özuyanık O. 2004. A research on adaptation mechanisms of Damascus goats grown in arid climate conditions of Turkish Republic of Northern Cyprus. Master's Thesis, Institute of Natural and Applied Sciences University of Çukurova, Adana, Turkey.

Pesmen G, Yardimci M. 2008. Estimating the live weight using some body measurements in Saanen goats. Arch Zootech 11, 30-40.

Sariyel V. 2013. Adaptation and some production characteristics of Saanen goats raised under intensive conditions in Konya province. $P h D$ Dissertation, Institute of Natural and Applied Sciences University of Selçuk, Konya.

SAS. Statistical Analysis System. 2018. SAS version 15.1. SAS Inst Inc., Cay, NC, USA.

Şimşek ÜG, Bayraktar M, Gürses M. 2007. Investigation of growth rate and survivability characteristics of Pure Hair goats and Saanen x Pure Hair goats crossbreeds $\left(\mathrm{F}_{1}\right)$. Firat J Health Sci 21, 21- 26.

Tozlu Çelik H, Oflaz M. 2015. Comparison of Hair goat and Saanen x Hair goat crossbred $\left(\mathrm{F}_{1}, \mathrm{G}_{1}\right)$ raised at the farm conditions in terms of fertility characteristics . Turkish JAF Sci Tech 3, 164-170.

TUIK, Turkish Statistical Institute. 2017. Livestock Statistics. Turkish Statistical Institute, Istanbul, Turkey.

Tuncel E, Bayındır Ş. 1983. Genetic improvement of goats in Turkey. European Society of Animal Breeding Symposium, October 17-21, Ankara, Turkey.

Ünalan A, Ceyhan A. 2017. Determination of sex effect on body weight and some body measurements of Kilis goat. Harran J Agri Food Sci 21, 219-226. 